\title{
The EU perspective not for Sarajevo? Bosnia and Herzegovina's integration with the European Union: opportunities, challenges and perspectives
}

In 2018 the European Union (EU) - presenting a new strategy for the enlargement policy, organizing the official summit of the state leaders and devoting to potential accessions the meeting of the Council - recalled that the future of the Western Balkans lies in the EU. The vision of an "European (Union) future" was announced to the Balkan countries fifteen years earlier, in 2003, when they were recognized as potential candidates for membership in the EU. According to the Article 49 of the Treaty on European Union, "Any European State which respects the values referred to in Article $2^{1}$ and is committed to promoting them may apply to become a member of the Union" (Treaty on European Union, article 49).

At the end of the second decade of the $21^{\text {st }}$ century, the Balkan countries are at various stages of their integration with the European Union. One of them - Croatia - joined the EU in 2013. Some were granted candidate statuses (Albania, the former Yugoslav Republic of Macedonia, Montenegro and Serbia) and started accession negotiations (Montenegro and Serbia). Others - Bosnia and Herzegovina (BiH) and Kosovo - are still considered as potential candidates. Nevertheless, in 2016 Sarajevo decided to apply for membership in the European Union.

Therefore, the main aim of this article is to analyze the possibility of joining the European Union by Bosnia and Herzegovina. It is necessary to identify - even if chosen - opportunities and challenges, perspectives and barriers (above all, on the political and economic level) on the path to further integration of Sarajevo with Brussels. The background to these considerations must be the European Union's policy towards the Western Balkans region, which lost its dynamics with the beginning of the second decade of the $21^{\text {st }}$ century, and is trying to retrieve it for various reasons nowadays. Will Bosnia and Herzegovina benefit from the intensification of the EU's enlargement policy?

\section{Context: the European perspective of the Western Balkans}

The European Union, which did not show its effectiveness in solving the armed conflict in the Balkans in the last decade of the $20^{\text {th }}$ century, as a compensation for the

1 Article 2: "The Union is founded on the values of respect for human dignity, freedom, democracy, quality, the rule of law and respect for human rights, including the rights of persons belonging to minorities. These values are common to the Member States in a society in which pluralism, nondiscrimination, tolerance, justice, solidarity and equality between women and men prevail" (Treaty on European Union, article 2). 
countries of the Peninsula, decided to become more involved in the process of stabilization and development of the region. The European Council in 1995 welcomed the singing of the Dayton agreement, ending the war in the former Yugoslavia, at the same time declaring its determination to support the implementation of the agreement (Presidency Conclusions, December 1995). Soon (in February 1996) the EU decided to apply to the countries of the Western Balkans the so-called regional approach, that did not differentiate the EU's policy towards particular countries in that area, and which emphasized the improvement and strengthening of political, economic and social relations between them (Petričušić, 2005, p. 5). In subsequent years, the EU institutions focused primarily on expressing satisfaction with the progress achieved by the Balkan states on their way to stabilization, alternately showing their concerns about the slow pace of changes, while at the same time declaring support for the initiated reforms (Presidency Conclusions, June 1996; Presidency Conclusions, June 1997; Presidency Conclusions, December 1998).

In the face of low effectiveness of the yet carried out activities (mainly in the form of regularly presented declarations, but also humanitarian aid and development cooperation), the impetus for the actual contribution in strengthening peace, stability and prosperity, as well as strengthening cooperation between the Balkan states, was to come in 1999. The European Council confirmed then "the readiness of the European Union to draw the countries of this region closer to the prospect of full integration into its structures" (Presidency Conclusions, June 1999). For this purpose the EU initiated, on 10 June 1999, the Stability Pact for South-Eastern Europe (SPSEE) (Hombach, 2000, passim) and, next, the Stabilisation and Association Process (SAP), which modified the regional approach to the Balkan states. More emphasis was put on the internal situation of individual countries. Their participation in the process and the level of its advancement resulted in greater incentives for interested countries, including financial ones (Schenker, 2008, p. 17).

The reality of the membership perspective was confirmed at the next summits of the European Council, for example in Lisbon (March 2000), Santa Maria de Feira (June 2000), or at the EU - Western Balkans summit in Zagreb (November 2000). During that meeting the CARDS program was launched, for technical and financial assistance of the reconstruction, development and stabilization. For the years 2000-2006 4.65 billion EUR was allocated under this instrument. In 2007 the CARDS program was replaced by the Instrument for Pre-Accession Assistance (IPA), assuming support at the level of 11.5 billion EUR in 2007-2013 and 11.7 billion EUR in 2014-2020 (Instrument).

In 2003, during the March summit of the European Council, it was clearly stated that, "the future of the Western Balkans lies in the European Union" (Presidency Conclusions, March 2003). In June the Council emphasized its "determination to fully and effectively support the European perspective of the Western Balkan countries, which will become an integral part of the EU, once they meet the established criteria" (Presidency Conclusions, June 2003). Moreover, the Thessaloniki Agenda for the Western Balkans was approved. The purpose was to further strengthen the privileged relations of the EU and the Balkan states, and to enrich the framework for the European course of these countries, up to their future accession (without specifying the dates of accession). The Agenda mentioned the upcoming historic enlargement of the 
EU to the countries of the Central and Eastern Europe and indicated that this event should become an inspiration for the countries of the Western Balkans. Nonetheless, the document remarked that the pace of the integration with the EU depends only on themselves (EU - Western Balkans Summit). One of the tools to intensify the stabilization and association process, identified in the Thessaloniki Agenda, was the European Partnership (covering Albania, Bosnia and Herzegovina, the former Yugoslav Republic of Macedonia, Croatia, Montenegro and Serbia and Kosovo) (Council Regulation, (EC) No. 533/2004).

In the following years, satisfaction was expressed with the progress made by the Balkan countries in the stabilization and association process and in their adjustment efforts aimed at reaching the EU standards. Declarations about the "European future" of the region were repeated, for example, at the EU - Western Balkans summit held in March 2006 in Salzburg (Salzburg EU/Western Balkans) or during the ministerial meeting which took place in Sarajevo in June 2010 (EU to reaffirm).

Nevertheless, since the beginning of the second decade of the $21^{\text {st }}$ century, the enlargement policy towards the Western Balkans has been constantly giving way to topics that were more important for the Member States. Internal reforms, the economic and financial situation (along with reacting to the global economic crisis and the crisis in the euro area), the refugee-migration crisis, the fight against terrorism, Brexit - the biggest attention was paid to these issues in the public debate. ${ }^{2}$ It also, on the one hand, affected the ability of the European Union to absorb new members and, on the other hand, weakened the attractiveness of membership in the organization. Especially since Jean-Claude Juncker, taking over the office of the President of the European Commission in 2014, clearly stated, "The EU needs to take a break from enlargement so that we can consolidate what has been achieved among 28. This is why, under my Presidency of the Commission, ongoing negotiation will continue, and notably the Western Balkans need to keep a European perspective, but no further enlargement will take place over the next five years" (Juncker, 2014, p. 12).

So far, the European perspective of the Western Balkans did come true only for Croatia which became the $28^{\text {th }}$ Member State of the European Union on 1 July 2013. One of the most important implications of Croatia's accession has been the continuation (though not very dynamic) of the Balkan direction in the EU's enlargement policy (Górecki, 2016, p. 190), which may strengthen Zagreb's position as a link between the Union and the region (Żornaczuk, 2013, pp. 1-2). Mainly, because other Balkan countries also taken up the integration challenge. The former Yugoslav Republic of Macedonia received the candidate country status on 16 December 2005, Montenegro on 17 December 2010, Serbia on 1 March 2012 and Albania on 27 June 2014. Moreover, Montenegro and Serbia are already conducting accession negotiations. In addi-

${ }^{2}$ More information about the EU's crises and their consequences: Stolarczyk M. (2012), Implikacje kryzysu Unii Europejskiej dla dalszego procesu integracji, "Krakowskie Studia Międzynarodowe," no. 3; Kryzysy w procesie integracji europejskiej i sposoby ich przezwyciężania (2015), eds. K. A. Wojtaszczyk, J. Nadolska, Warszawa; Fiszer J. M. (2015), Kryzys integracji europejskiej czy kryzys Unii Europejskiej? Przesłanki i skutki, "Przegląd Europejski," no. 3 (37); Stolarczyk M. (2016), Gtówne przyczyny i przejawy kryzysów w Unii Europejskiej oraz ich implikacje dla dalszego procesu integracji europejskiej, "Roczniki Nauk Społecznych,” t. 8 (44), no. 3. 
tion, two countries are still considered as potential candidates for membership in the European Union: Kosovo (cooperating with the EU, inter alia, under the Stabilization and Association Process) and Bosnia and Herzegovina which decided to submit an accession application in 2016 (Enlargement).

Notwithstanding, attention should be paid to the fact that the enlargement issue was again raised by the European Union at the end of the second decade of the $21^{\text {st }}$ century. On 6 February 2018 a new document was presented: A credible enlargement perspective for and enhanced EU engagement with the Western Balkans. Thus, it was recalled that a credible prospect of enlargement requires credible efforts and reform in the Western Balkans along with the European Union's support (European Commission, COM (2018) 65). It was highlighted that, "the future of the region as an integral part of the EU is in the Union's very own political, security and economic interest. The EU's enlargement policy is part and parcel of the larger strategy to strengthen the Union by 2025" (Ibidem). The document also set out six flagship initiatives to be implemented in 2018-2020, regarding: the rule of law, security and migration, socio-economic development, transport and energy connectivity, the Digital Agenda and reconciliation and good neighbourly relations. They are considered as "new prospects for resolving old challenges" (Żornaczuk, 2018, pp. 1-2).

What is more, in May 2018 in Sofia - for the first time since 2003 - the official summit EU - Western Balkans was organized. The new dynamics in the enlargement policy (also confirmed by the relevant conclusions adopted by the Council on 26 June 2018) may have at least several reasons. First one: the ineffectiveness of previous activities and the increase of the Euroscepticism in the Balkan countries, as a consequence of the too distant prospect of membership. Secondly, the need to achieve (despite numerous conflicts and crises) any success in the EU's policy. An last but not least - in the face of the EU's passivity - Russia, Turkey and China have strengthened their influences in that area (Western Balkans to 2025).

\section{Bosnia and Herzegovina in perception of the European Union}

Since the recognition of Bosnia and Herzegovina as a potential candidate country for the membership in the European Union (in 2003), both sides have signed a number of agreements and arrangements regulating bilateral cooperation. In 2004 the country was covered by the European Partnership (verified in 2006 and 2008) On 25 November 2005 the Stabilisation and Association Agreement was launched, which was signed on 16 June 2008 with the trade and trade-related issues agreement (that part of the deal entered into force on 1 July 2008). However, the proper agreement entered into force on 1 June 2015.

On 18 September 2007 visa facilitation and readmission agreements were signed, which entered into force at the beginning of 2008. In addition, from 15 December 2010 citizens of Bosnia and Herzegovina who have biometric passports can visa-free travel within the Schengen area.

Moreover, on 27 June 2012 both sides started the High-Level Dialogue on the Accession Process. That, among others, contributed to submitting by Bosnia and Herze- 
govina on 15 February 2016 an application for membership in the European Union. On 20 September 2016 the European Council asked the European Commission to give its opinion on this application. On 9 December 2016 the country received an appropriate questionnaire from the Commission, which - together with the responses - was returned in February 2018 (Enlargement - Bosnia and Herzegovina).

While awaiting for the European Commission's avis regarding the application, it is worth paying attention to the issues raised by the Commission in its regular (annual) reports on the progress of Bosnia and Herzegovina towards fulfilling the Copenhagen criteria (political criterion - stability of institutions guaranteeing democracy, the rule of law, respect for human rights, respect and protect of national minorities; economic criterion - functioning market economy, ability to cope with market competition within the EU; legal criterion - ability to accept and fulfil obligations resulting from membership, striving to achieve political, economic and monetary goals of integration) (Presidency Conclusions, June 1993). Numerous reservations were raised in almost every field that was covered by the analysis.

The first of the reports, presented in 2011, highlighted primarily the limited progress in implementing the European Partnership priorities, which required the implementation of measures to achieve more functional and sustainable institutional structures, as well as respect for human rights and fundamental freedoms, including harmonization of the constitution with the European Convention on Human Rights. Moreover, it pointed out: the existence of a long-term process of establishing legislative and executive power and the lack of government at the state level which diminish law-making capacity; lack of a common political vision of the directions of the state's development; slow reforms in the field of public administration and fragmentation as well as politicization of the civil service; little progress in the judiciary reforms; lack of effectiveness of anti-corruption activities; little progress in improving the enforcement of international human rights legislation and the need to reform the prison system (European Commission, SEC (2011) 1206). Similar issues were noted in the following years: through the fragmentation of power, political consensus about its functioning (also at the local level) has still not been achieved. The Commission noted, in addition, an imbalance in the protection of rights - economic and social rights are respected, labour rights should be strengthened, but minority discrimination is widespread, although the minorities are protected better (European Commission, COM (2012) 600; European Commission, COM (2013) 700).

Regarding to the economic criterion, in 2011 firstly noted was the frailty of the consensus about the foundations of the country's economic and fiscal policy. Furthermore, the economic weakness of Bosnia and Herzegovina was mentioned, manifesting itself in unfavourable macroeconomic results of the country, rising inflation, poor condition of the labour market, high level of unemployment or the existence of an unfavourable business environment (low rule of law, corruption). The ability to cope with the competition on the EU market was undermined, but the high level of trade integration between Bosnia and Herzegovina and the European Union was noted (European Commission, SEC (2011) 1206). Also in the following years insufficient progress was made to meet the economic criteria, especially in the scope of functioning of the free market economy. Coping with the competition forces of the EU market (in the long-term) 
would be possible for the country only after determined economic reforms (European Commission, COM (2012) 600; European Commission, COM (2013) 700).

Numerous inconsistencies and maladaptation were mentioned in 2011 also in relation to the fulfilment of the legal criterion (European Commission, SEC (2011) 1206). It was further emphasized that due to the lack of political support for the European perspective of Bosnia and Herzegovina there was a very limited progress in terms of alignment with the EU law and the EU standards. Discrepancies have arisen particularly in the areas of veterinary policy and food safety policy, competition, public procurement, energy, the environment and climate change, transport, employment, and social policy (European Commission, COM (2012) 600; European Commission, COM (2013) 700).

These problems were also noted in 2014 (European Commission, COM (2014) 700), 2015 (European Commission, SWD (2015) 214) and 2016 (European Commission, SWD (2016) 365). The last of the regular reports was published in 2018.

Once again, the report pointed out many weaknesses of the political and economic situation in Bosnia and Herzegovina and the maladjustment of its legislation to the EU law. The Commission's remarks mainly concerned:

- the impossibility to achieve a political consensus by the state (the Presidency, the Council of Ministers) about both foreign policy and internal affairs;

- small progress in implementing the public administration reform; further fragmentation of civil services increases the risk of politicization;

- little progress in implementing the judiciary reform;

- little progress in the implementation of anti-corruption and organized crime legislation;

- some progress in the protection of human rights and minority issues; however, further efforts are needed in the area of freedom of expression, especially in the face of political pressure and intimidation of journalists, including verbal and physical attacks; ineffective implementation of the law on prevention and protection against gender-based violence;

- some progress in terms of economic development and competitiveness, but the state is still in the early stages of creating a functioning market economy;

- some progress in improving the situation of the business environment and strengthening the financial sector; however, there is still a weak rule of law, divided and inefficient public administration, a serious imbalance in the labour market, as well as a weak education system that does not support the investment climate; great importance of the informal economy;

- some progress towards achieving the capacity to cope with the competitive pressure and market forces in the European Union; nevertheless: small expenditures are incurred for education, research and development; visible underinvestment of human capital, deficits in the field of transport and energy infrastructure; low rate of structural adjustments (European Commission, SWD (2018) 155).

Therefore, it can be stated that the position of Bosnia and Herzegovina in the reports prepared by the European Commission is not particularly favourable. Meanwhile, the opinion issued by that EU institution (avis) may set the direction for the further integration of the state with the European Union (the Commission's recom- 
mendations are usually taken into account by the European Council, giving the status of a candidate country, although not necessarily when the case concerns starting the accession negotiations).

Nonetheless, it is worth noting that a very general and extensive approach to the Copenhagen criteria (which level of fulfilment shapes the Commission's avis) makes it impossible to interpret them unequivocally. The European Council did not develop precise indicators, by which the criteria would be verified. On the one hand, this may cause a threat of delaying the beginning of the accession procedure by the European Union, while on the other hand - it gives Bosnia and Herzegovina a chance that the state's application will not be rejected.

\section{Integration of Bosnia and Herzegovina with the European Union: opportunities and challenges. Selected issues}

Bosnia and Herzegovina remains the state with the most complicated structure of the system and political situation in the Western Balkans - the goal of the agreement developed in Dayton in 1995 was to create a framework in which three ethnic and political communities (Bosnians, Croats and Serbs), previously fighting in a civil war, could operate seamlessly as a state (Gavrić, Banović, Barreiro, 2013, pp. 16-17). Under this agreement Bosnia and Herzegovina functions as an union of two entities: the Republika Srpska and, the Bosnian and Croatian, Federation of Bosnia and Herzegovina, which are subordinated to a centralized government with limited competences (Bojkov, 2003, pp. 42-43). In 2000 the Brczko District, which is directly subordinated to the central power, was also separated, being the third component of the federation, though without taking this fact into account by the constitution.

The aim of the agreement prepared in 1995 by the presidents of Bosnia and Herzegovina, Serbia and Croatia, under the auspices of the international community, was (in the face of the ongoing war) primarily preserving Bosnia and Herzegovina as a state. Dayton agreement imposed the constitution of Bosnia and Herzegovina, creating weak central institutions and two units. Established constitutional order, institutionalizing the multiethnicity of the state and leaving to its parts a lot of autonomy (although the constitution itself does not specify the competences of entities; Constitution of Bosnia and Herzegovina) is a subject of constant criticism and enables articulating further independence aspirations of particular groups (Eralp, 2012, pp. 31-37). Nevertheless, it remains nearly unchanged (Muś, 2013, pp. 91-96).

Multiethnicity and equality of all communities at the highest level mean for instance holding the office of the head of the state by a collegial body. A number of specific provision have been introduced to functioning of the Parliamentary Assembly, also the constitutional court is not lacking of originality (Krysieniel, 2014, pp. 48-51). However, it should be noted that the main consequence of the constitutional provisions for the political system of Bosnia and Herzegovina is the occurrence of many elements, which are called directly dysfunctional. Krzysztof Krysieniel mentions among them, "a) creating two units (entities) with different territorial and administrative structures $[\ldots]$; b) converting Bosnia and Herzegovina into a semi-protectorate through 
establishing an institution of the High Representative of the International Community $[\ldots]$; c) no decision concerning the territorial affiliation of the strategically located city of Brczko [...]; d) weak central authorities, resulting in, for example, difficulties with unification of the army and police services, border control, the introduction of the single currency, and even passports; e) differences in the political system of Republika Srpska and the Federation which lead to discrimination on the basis of nationality, religion, and even education or economics; f) an extremely complicated way of making decisions" (Krysieniel, 2010, pp. 167-168).

Solutions aiming at enabling the functioning of the state, in practice lead to the paralysis of the political process - an extensive institutional system (also at the component level of the country) provides many opportunities for blocking political initiatives (Stanisławski, Szpala, 2009, pp. 27-30) or developing corruption. In the Corruption Perceptions Index 2017 Bosnia and Herzegovina was classified on the $91^{\text {st }}$ position - only the former Yugoslav Republic of Macedonia was ranked below as an European country, on the $107^{\text {th }}$ place (Corruption Perceptions Index). According to estimates from $2014,22.9 \%$ of adult citizens were urged to give a bribe, from whom $15.9 \%$ succumbed that pressure (Anti-Corruption).

The main factor that blocks the integration of Bosnia and Herzegovina with the European Union is therefore the political situation of that country. Wojciech Stanisławski and Marta Szpala, analysing the sources of the crisis in contemporary Bosnia and Herzegovina, pointed out several basic causes of the "Bosnian chaos." First of all, that country still has not dealt with the legacy of the civil war in 19921995, the free market modernization of the economy and the democratization of the state. Moreover, the political elites do not seek to overcome conflicts, but to preserve them. Secondly, there are fundamental differences between the Bosnian and Serbian political forces in understanding the national interest. As the third reason analysts point out the contradiction in the activities of the international community, which on the one hand - strives to establish a post-war order in the state and - on the other hand - recognizes the right to subjectivity of nations living in it (Stanisławski, Szpala, 2009, pp. 5-7). However, the researchers suggest that, "it seems highly probable that the international community (including the EU in the first place) will be given the ungrateful role of the stabilizer, which is not ready to impose complex political solutions for the conflicted political elites of $\mathrm{BiH}$, but was forced to take responsibility for the inability to independent functioning of the area" (Ibidem). The fact is that EU activities are a permanent element of the region's stabilization system and "the Western Balkan countries represent a special challenge for the EU and require its continued commitment, both political and financial, to work towards political and economic stability and to support the process of system transformation in the region" (Batkany Zachodnie).

Ethnic division and political rivalry within individual communities are also associated with diverse concepts of functioning of the state in general: the Bosnian elites are mainly in favour of the "unitarist" concept (full unification of Bosnia and Herzegovina), while the Serbian elites promote the federalist vision of the country and maintaining a wide autonomy for the Serbian part (Stanisławski, 2008, p. 42). Regularly returning are the proposals to divide the country (Sarajlic-Maglic, 2011, p. 54) and 
distribute it to other entities. ${ }^{3}$ The strong and so far unresolved political conflict is seen by the citizens as the corruption and ineffectiveness of the political class playing only inter-ethnic animosities. Combined with the difficult economic situation, it led to the largest since the end of the civil war demonstrations at the beginning of the 2014 (Dzidic, 2014). The state's inability to cope with the effects of the flood that appeared in the Western Balkans in May 2014 did not reduce the public frustration (Jukic, 2014).

Despite the fact that integration with the European Union is finally perceived as a priority for the authorities of Bosnia and Herzegovina (it was possible to work out a relative political consensus which can be proved by applying for the EU membership), the accession process itself is interwoven with fundamental problems related to the discrepancy vision of the future of the state and the progressive erosion of its institutions (Babić, 2011, p. 132).

The failure of the institutional system which is functioning in Bosnia and Herzegovina confirms that in the long term tensions may become a challenge for the international community, mainly for the European Union from which a greater degree of determination in imposing specific legal, systemic and administrative solutions will be required (especially because the risk of stopping the integration process does not change the proceeding of the political elites) (Stanisławski, 2008, pp. 48-49). However, the EU actions for the domestic dialogue on constitutional reforms and a clear indication that the cooperation of the country's authorities in the field of democratization will strengthen the prospect of rapprochement with the EU, should be continued (Joniewicz, Żornaczuk, 2012, pp. 1-2).

It could be also valuable to hold a referendum among the citizens of Bosnia and Herzegovina, which would express the public opinion on the issue of the integration of the state with the European Union. Recognition of integration as the overriding goal of the whole country's society may additionally serve as one of the most effective forms of pressure on the ruling elite (Babić, 2011, p. 154). Especially because in 2010 the $88.2 \%$ of the citizens of the country were supporters of Bosnia and Herzegovina's membership in the EU (88.2\% of the citizens). However, the low level of advancement of the integration caused the decline in favour towards state's accession (Balkan Barometer 2017), although the European Union is still perceived as a recipe for many problems affecting the country (Public Opinion Poll Results).

Considering such fundamental issues - concerning even the shape of the state - it is difficult to expect that specific requirements resulting from the political Copenhagen criterion will be met. However, it should be noted that in the case of the Balkan states the European Union - in assessing the progress made by candidate and potential candidate countries - also takes into account the cooperation with the International Criminal Tribunal for the former Yugoslavia and the advancement of regional cooperation. Bosnia and Herzegovina achieves acceptable results in both these fields according to the European Commission. In 2011 the Commission stated that the country's work with the ICTY was satisfactory (a number of important steps were taken to trial the war crimes) and that the state "continued to participate actively in regional cooperation and to maintain good neighbourly relations" (although further, determined actions

${ }^{3}$ These proposals relate to the concept of division of the state promoted in early 1990s by the Croatian President, Franjo Tudman. More information: P. Żurek (2011), Bośnia i Hercegowina w wizji politycznej Franjo Tudmana, in: Bośnia i Hercegowina 15 lat po Dayton. Przeszłość - teraźniejszość - perspektywy, eds. P. Chmielewski, S. L. Szczesio, Łódź. 
were necessary in some cases, for example related to borders) (European Commission, SEC (2011) 1206, p. 23). The bilateral relations of Bosnia and Herzegovina with the majority of countries in the region in 2018 were similarly assessed. However, there are doubts about whether the inter-Balkan relations are indeed stable, or they are merely an ostensible success of the European Union in that area (Szpala, 2011).

Furthermore, in the reports on Bosnia and Herzegovina the European Commission regularly draws attention to the country's insufficient compliance of the requirements included in the economical Copenhagen criteria. Deficits in the functioning of the free market reduce (unless they completely undermine) also the state's ability to cope with competitive pressure and market forces in the European Union.

Other analysts also pay attention to similar issues. The economy of the state is recognized not only on the scale of the EU, but also on the world scale as an uncompetitive. In The Global Competitiveness Index 2017-2018 Bosnia and Herzegovina was ranked on the $103^{\text {rd }}$ position (The Global Competitiveness Report). Innovations also are not included in the specificity of the country - The Global Innovation Index 2017 placed Sarajevo on the $86^{\text {th }}$ place (The Global Innovation Index). Unfavourable role in improving that situation play for example inefficient government bureaucracy, corruption, instability of governments and policies, tax regulations, access to financing or inadequate education of the workforce, considered as the main obstacles to business operations (Bosnia and Herzegovina. Key Indicators).

The economic weakness of Bosnia and Herzegovina (especially in comparison to the EU Member States) represents the GDP per capita index, measured by the purchasing power parity of residents. It needs to be highlighted that this factor, among others, affects on the amount of funds allocated for particular countries in the EU budged under the cohesion policy.

In 2010 that country reached only $29 \%$ of the EU average in this category, while in 2017 it was $32 \%$. This is a result that is incomparable to that achieved annually by Luxembourg and also significantly lower than the result of Bulgaria which is the least developed Member State of the European Union. Bosnia and Herzegovina in this measure slightly lags behind the other candidate countries. However, it may be a chance for Sarajevo that Albania, which has recorded weaker results, in 2014 was granted the status of a candidate country.

Table 1

\section{GDP per capita (PPS, \%) in 2010-2017 in the European Union and Balkan candidate} and potential candidate countries

\begin{tabular}{||l|c|r|r|r|r|r|r|r||}
\hline \hline & $\mathbf{2 0 1 0}$ & $\mathbf{2 0 1 1}$ & $\mathbf{2 0 1 2}$ & $\mathbf{2 0 1 3}$ & $\mathbf{2 0 1 4}$ & $\mathbf{2 0 1 5}$ & $\mathbf{2 0 1 6}$ & $\mathbf{2 0 1 7}$ \\
\hline UE- 28 & 100 & 100 & 100 & 100 & 100 & 100 & 100 & 100 \\
\hline LU & 257 & 265 & 260 & 261 & 270 & 267 & 257 & 253 \\
\hline BG & 44 & 45 & 46 & 46 & 47 & 47 & 49 & 49 \\
\hline ME & 41 & 42 & 39 & 41 & 41 & 42 & 45 & 46 \\
\hline XS & 36 & 37 & 37 & 38 & 37 & 36 & 37 & 37 \\
\hline MH & 34 & 34 & 34 & 35 & 36 & 36 & 37 & 37 \\
\hline BA & $\mathbf{2 9}$ & $\mathbf{3 0}$ & $\mathbf{3 0}$ & $\mathbf{3 0}$ & $\mathbf{3 0}$ & $\mathbf{3 0}$ & $\mathbf{3 1}$ & $\mathbf{3 2}$ \\
\hline AL & 29 & 29 & 30 & 29 & 30 & 29 & 29 & 29 \\
\hline
\end{tabular}

Data source: Eurostat, GDP per capita in PPS, Ec.europa.eu, http://ec.europa.eu/eurostat/tgm/table.do?ta $\mathrm{b}=$ table\&init $=1 \&$ language $=$ en \&pcode $=$ tec00114\&plugin $=1,30.06 .2018$. 
At the same time it is worth noting that Bosnia and Herzegovina in the second decade of the $21^{\text {st }}$ century achieves relatively good macroeconomic results. In terms of inflation, public debt or budget deficit, its results are frequently better than results of the other EU Member States.

However, attention should be paid to several issues. Relative macroeconomic balance (both in terms of fiscal and monetary policy) is the basic condition for the state to receive external financing. Bosnia and Herzegovina whereas is eager to use, among others, the credit lines and financial support from the International Monetary Fund. For example: in 2016 the country received from the IMF, under the Extended Fund Facility, 555.3 million EUR (for three years) to implement the structural reform program, improve fiscal policy and strengthen the financial sector (IMF Executive Board Approves). The funds were directed primarily at the following activities: improving the functioning of the business environment in order to create jobs in the private sector and increase the growth potential; ensuring fiscal stability and improving the quality of government spending as well as securing financial stability, and reviving bank loans. In addition, "an important cross-cutting theme in the program are measures that strengthen the single economic space of $\mathrm{BiH}$, in accordance with the constitutional setup an competencies of respective institutions" (Bosnia and Herzegovina). Tranches are unlocked after realizing the program's objectives (IMF discusses unlocking loans) and these are possible - especially in the case of Sarajevo - only after reaching a political consensus. The experience of that country (e.g. in relation to difficulties with forming the government at the beginning of the second decade of the $21^{\text {st }}$ century) indicates that, "politicians in $\mathrm{BiH}$ are able to reach a compromise only in the case of a direct threat of collapse of the state finances. This will probably be used during granting $\mathrm{BiH}$ financial aid by the EU or the IMF - one should therefore expect it to be strictly conditioned by the introduction of economic and systemic reforms" (Szpala, 2012).

The relatively stable economic situation of the state, reflected by the basic macroeconomic results, being a derivative and a requirement of international institutions financing reforms in Sarajevo, can not, however, obscure the real problems that the economy of Bosnia and Herzegovina must face. The basic one, which also resonates on the social situation of the country, is the high unemployment rate - much higher that the EU average and the results of the particular Member States which are the most favourable in this category (Austria, Germany, the Czech Republic). Nevertheless, comparable with the countries that were most severely affected by the economic crisis (Spain, Greece).

Table 2

Unemployment rate (\%) in 2010-2017 in the European Union and Bosnia and Herzegovina

\begin{tabular}{|l|r|r|r|r|r|r|r|r||}
\hline & $\mathbf{2 0 1 0}$ & $\mathbf{2 0 1 1}$ & $\mathbf{2 0 1 2}$ & $\mathbf{2 0 1 3}$ & $\mathbf{2 0 1 4}$ & $\mathbf{2 0 1 5}$ & $\mathbf{2 0 1 6}$ & $\mathbf{2 0 1 7}$ \\
\hline UE-28 & 9,6 & 9,7 & 10,5 & 10,9 & 10,2 & 9,4 & 8,6 & 7,6 \\
\hline Best result & 4,6 & 4,6 & 4,9 & 5,2 & 5,0 & 4,6 & 4,0 & 2,9 \\
& $(\mathrm{AT})$ & $(\mathrm{AT})$ & $(\mathrm{AT})$ & $(\mathrm{DE})$ & $(\mathrm{DE})$ & $(\mathrm{DE})$ & $(\mathrm{CZ})$ & $(\mathrm{CZ})$ \\
\hline Worst result & 19,9 & 21,4 & 24,8 & 27,5 & 26,5 & 24,9 & 23,6 & 21,5 \\
& $(\mathrm{ES})$ & $(\mathrm{ES})$ & $(\mathrm{ES})$ & $(\mathrm{GR})$ & $(\mathrm{GR})$ & $(\mathrm{GR})$ & $(\mathrm{GR})$ & $(\mathrm{GR})$ \\
\hline BA & $\mathbf{2 7 , 2}$ & $\mathbf{2 7 , 6}$ & $\mathbf{2 8 , 0}$ & $\mathbf{2 7 , 4}$ & $\mathbf{2 7 , 5}$ & $\mathbf{2 6 , 2}$ & $\mathbf{2 5 , 0}$ & b/d \\
\hline \hline
\end{tabular}

Data source: Eurostat, Total unemployment rate (\%), Ec.europa.eu, http://ec.europa.eu/eurostat/tgm/table. do?tab=table\&init=1\&language=en\&pcode=tps00203\&plugin=1, 30.06.2018; The World Bank, Unemployment, total (\% of total labor force) (national estimate), Data.worldbank.org, https://data.worldbank. org/indicator/SL.UEM.TOTL.NE.ZS?locations=BA\&name_desc=false, 30.06.2018. 
Nonetheless, it is difficult to define the credibility of this data in relation to Bosnia and Herzegovina. Especially considering the estimates that even $1 / 3$ of the country's GDP may be additionally generated by the informal economy (Medina, Schneider, 2018 , p. 69), in which up to $37 \%$ of employees with other legal sources of income can be involved (Hidden Economy, 2016, p. 4). It is practically impossible to calculate what percentage of Bosnia and Herzegovina's citizens actually (from not only employed, but also the unemployed) drives the "shadow economy" income. Moreover, the political, economic and social situation of the country is conducive to the functioning of organized crime, intensified during the war in the last decade of the $20^{\text {th }}$ century and still remaining a major problem in the second decade of the $21^{\text {st }}$ century (Brady, 2012, pp. 16-23). However, in this context, Bosnia and Hercegovina is similar to other countries of the Balkan region (Stojarova, 2007, p. 98).

Taking that into account, as well as the significant disproportions in the level of the economic development of Bosnia and Herzegovina and the EU Member States, the biggest doubts concern whether this organization is able - in the second decade of the $21^{\text {st }}$ century - to generate further deposits of (financial) solidarity (Molendowski, 2012, p. 38). On the one hand, the Union has the mission to support the well-being of its peoples and "the economic, social and territorial cohesion and solidarity between the Member States" (Treaty on European Union, article 3). It also feels responsible for moderate stabilization of the situation in its environment - thanks to that Sarajevo already received 412 million EUR in 2001-2006 under the CARDS program, 656 million EUR in 20072013 under the IPA initiative and 167 million EUR in 2014-2017 from IPA II (excluding funds for cross-border activities) (Bosnia and Herzegovina - financial assistance).

On the other hand, more and more intense discussion about the EU budget, polarization of opinions about the cohesion policy or common agricultural policy, internal division into members of the euro zone and countries outside of it, controversies about the distribution of funds between members of the "old" and the "new" Union and development disparities between the countries of the Western Europe and Central and Eastern Europe confirm, that the organization should focus on the consumption of previous enlargements and the elimination of existing differences. In the face of numerous internal conflicts and crisis (also with the financial background) among the Member States, enlargement policy is not a priority for the Union. The priority should be to strengthen, also weakened, the EU solidarity, ${ }^{4}$ what is being recalled by the part of the European leaders and the leaders of the various EU institutions.

\section{Summary: the EU perspective not for Bosnia and Herzegovina?}

As it was previously mentioned, the 2018 strategy indicated that enlargement policy is one of the ways of strengthening the European Union by year 2025. It added

${ }^{4}$ Read more: A. Raspotnik, M. Jacob, L. Ventura (2012), The issue of solidarity in the European Union, "TEPSA Brief," 8.08.2012; Solidarity in the European Union: Challenges and Perspectives (2017), ed. A. Giannakopoulos, "Research Paper," no. 9, The S. Daniel Abraham Center for International and Regional Studies, July; Solidarity in Europe. Citizens' Responses in Times of Crisis (2018), eds. Ch. Lahusen, M. T. Grasso, Cham. 
that "with strong political will, delivery of real and sustained reforms, and definitive solutions to disputes with neighbours, Serbia and Montenegro could potentially be ready for membership by this date," but "accession is and will remain a merit-based process fully dependent on the objective progress achieved by each country" (European Commission, COM (2018) 65, p. 17). Can Bosnia and Herzegovina also take advantage from intensifying the EU enlargement policy? The strategy only emphasises that, "with sustained effort and engagement, Bosnia and Herzegovina could become a candidate for accession" (Ibidem, p. 7). These (rather general) declarations can again be seen as maintaining the "European perspective" for the Western Balkans, which has been already put in a time frame for two countries. That is a novelty in the European Union's policy towards the region, which may be the premise for strengthening motivation and commitment to the implementation of adjustment processes by both sides, the Balkan states as well as the EU.

In relation to Bosnia and Herzegovina, it should be emphasized that the difficult political, economic and social situation still implies a low level of fulfilment of the Copenhagen criteria. In June 2018 the Council of the European Union underlined that, "the Council welcomes the adoption of some EU-oriented reforms in Bosnia and Herzegovina" (Council of the European Union, 2018, p. 20) and that, "the Council further reiterates its unequivocal commitment to Bosnia and Herzegovina's EU perspective as a single, united and sovereign country" (Ibidem, p. 22). However, the Council also revealed many problems of this state (the Council "encourages all authorities and political forces in Bosnia and Herzegovina to overcome divisive rhetoric rooted in the past, to end the glorification of convicted war criminals as well as to actively promote reconciliation") (Ibidem) and pointed out numerous deficits in its functioning ("the Council notes with concern that divisive rhetoric and pre-electoral campaigning have significantly slowed down the pace of reforms, particularly as regard the Reform Agenda") (Ibidem, p. 20). Shortcomings have been reported in relation to (inter alia) socio-economic reforms, the rule of law, anti-corruption and organized crime fight, combating radicalization and terrorism, the functioning of public administration, protection of freedom of expression and building independent media, electoral law provisions, hostile business environment, lack of common economic space, fragmented regulatory environment, and imbalances in the labour market (Ibidem, pp. 21-23).

Nevertheless, despite these weaknesses, it is worth the risk to state - taking into account the experience of other Balkan countries - that Bosnia and Herzegovina will soon be granted the status of the EU candidate country, which obviously will not guarantee accession in the foreseeable future. This status (as a confirmation of the relatively high level of advancement on the European integration for a country staying outside the organization) may, for the conflicted Bosnian political forces, motivate and justify reforms and become an ultimate platform for cooperation. It seems that, "in the face of internal contradictions, the lack of shared vision of the state and a full willingness to cooperate between constitutive nations, Bosnia and Herzegovina has a chance to survive only when it becomes a part of a larger, supranational organism - the European Union" (Krysieniel, 2011, p. 478). However, any further steps on the road to full integration will require the state's maturity (coherence) in perceiving the national 
interest, what is still difficult at the end of the second decade of the $21^{\text {st }}$ century - after more than twenty years after the constitution of the Daytonian order.

\section{Bibliography}

88.2\% of the citizens suport the EU membership of Bosnia and Herzegovina, 28.03.2011, Dei.gov. ba, http://www.dei.gov.ba/dei/media_servis/vijesti/default.aspx?id=7334\&langTag=en-US, 30.06.2018.

Anti-Corruption Reloades. Assessment of Southeast Europe (2014), Southeast European Leadership for Development and Integrity, Sofia.

Babić M. (2011), Bałkanizacja czy europeizacja? Bośnia i Hercegowina w perspektywie europejskiej, in: Konflikty narodowe i europejskie aspiracje państw batkańskich, ed. M. Filipowicz, Lublin.

Balkan Barometer 2017. Public Opinion Survey (2017), "Regional Cooperation Council," no. 3.

Bałkany Zachodnie a integracja europejska. Perspektywy i implikacje (2008), eds. R. Sadowski, J. Muś, Warszawa.

Bojkov V. D. (2003), Democracy in Bosnia and Herzegovina: Post-1995 Political System and its Functioning, "Southeast European Politics," vol. IV, no. 1.

Bosnia and Herzegovina - financial assistance under IPA II, Ec.europa.eu, https://ec.europa.eu/ neighbourhood-enlargement/instruments/funding-by-country/bosnia-herzegovina_en, 30.06.2018.

Bosnia and Herzegovina (2018), International Monetary Fund, „IMF Country Report,” no. 18/39, February.

Bosnia and Herzegovina. Key Indicators 2015 (2016), World Economic Forum, Executive Opinion Survey.

Brady S. (2012), Organised Crime in Bosnia and Herzegovina. A silent war fought by an ambush of toothless tigers or a war not yet fought?, "Organized Crime and Corruption Reporting Project."

Constitution of Bosnia and Herzegovina, Ohr.int, http://www.ohr.int/?page_id=68220, 30.06.2018.

Corruption Perceptions Index 2017, Transparency International, https:/www.transparency.org/news/ feature/corruption_perceptions_index_2017,30.06.2018.

Council of the European Union, Enlargement and Stabilisation and Association Process - Council conclusions, Brussels, 26.06.2018, 10555/18, ELARG 41, COWEB 102.

Council Regulation (EC) No. 533/2004 of 22 March 2004 on the establishment of European partnership in the framework of the stabilisation and association process, Official Journal L 086, 24.03.2004, P. 0001-0002.

Dzidic D. (2014), Bosnia-Herzegovina hit by wave of violent protests, 07.02.2014, Theguardian. com, https://www.theguardian.com/world/2014/feb/07/bosnia-herzegovina-wave-violentprotests, 30.06.2018.

Enlargement - Bosnia and Herzegovina, European Neighbourhood Policy and Enlargement Negotiations, Ec.europa.eu, https://ec.europa.eu/neighbourhood-enlargement/countries/detailedcountry-information/bosnia-herzegovina_en, 30.06.2018.

Enlargement, European Neighbourhood Policy and Enlargement Negotiations, Ec.europa.eu, https:// ec.europa.eu/neighbourhood-enlargement/countries/, 30.06.2018.

Eralp D. U. (2012), Politics of the European Union in Bosnia-Herzegovina. Between Conflict and Democracy, Plymouth.

EU - Western Balkans Summit, Thessaloniki, 21 June 2003, Declaration, C/03/163, 10229/03, Presse 163. 
EU to reaffirm its commitment to Western Balkans at Sarajevo meeting, Brussels, 1 June 2010, $\mathrm{IP} / 10 / 647$.

European Commission, A credible enlargement perspective for and enhanced EU engagement with the Western Balkans, Communication from the Commission to the European Parliament, the Council, The European Economic and Social Committee and the Committee of the Regions, Strasbourg, 06.02.2018, COM (2018) 65 final.

European Commission, Bosnia and Herzegovina Progress Report 2014 accompanying the document Communication from the Commission 'Enlargement Strategy and Main Challenges 2014-15', Brussels, 08.10.2014, COM (2014) 700 final.

European Commission, Commission Staff Working Document - Bosnia and Herzegovina 2012 Progress Report accompanying the document Communication from the Commission to the European Parliament and the Council: Enlargement Strategy and Main Challenges 20122013, Brussels, 10.10.2012, SWD (2012) 335, COM (2012) 600.

European Commission, Commission Staff Working Document - Bosnia and Herzegovina 2013 Progress Report accompanying the document Communication from the Commission to the European Parliament and the Council: Enlargement Strategy and Main Challenges 20132014, Brussels, 16.10.2013, SWD (2013) 415, COM (2013) 700.

European Commission, Commission Staff Working Document. Bosnia and Herzegovina. 2015 Report accompanying the document Communication from the Commission to the European Parliament, the Council, the European Economic and Social Committee and the Committee of the Regions 'EU Enlargement Strategy', Brussels, 10.11.2015, SWD (2015) 214 final.

European Commission, Commission Staff Working Document. Bosnia and Herzegovina 2016 Report accompanying the document Communication from the Commission to the European Parliament, the Council, the European Economic and Social Committee and the Committee of the Regions '2016 Communication on EU Enlargement Policy', Brussels, 09.11.2016, SWD (2016) 365 final.

European Commission, Commission Staff Working Document. Bosnia and Herzegovina 2018 Report accompanying the document Communication from the Commission to the European Parliament, the Council, the European Economic and Social Committee and the Committee of the Regions '2018 Communication on EU Enlargement Policy', Strasbourg, 17.04.2018, SWD (2018) 155 final.

European Commission, Commission Staff Working Paper. Bosnia and Herzegovina 2011 Progress Report accompanying the document Communication from the Commission to the European Parliament and the Council Enlargement Strategy and Main Challenges 2011-2012, Brussels, 12.10.2011, SEC (2011) 1206 final.

Gavrić S., Banović D., Barreiro M. (2013), The Political System of Bosnia and Herzegovina. Institutions - Actors - Processes, Sarajevo.

Górecki M. (2016), Proces akcesyjny Chorwacji do Unii Europejskiej - implikacje dla dalszych rozszerzeń Wspólnoty, "Świat Idei i Polityki,” vol. 15.

Hidden Economy in Southeast Europe: Building Regional Momentum to Mitigate its Negative Effects (2016), Center for the Study of Democracy, Southeast European Leadership for Development and Integrity, Centre for Regional Enterprise and Economic Development, "Policy Brief," December.

Hombach B. (2000), Stability Pact for South-Eastern Europe: a new perspective for the region, "Perceptions," vol. V.

IMF discusses unlocking loans to Bosnia (2017), 18.12.2017, Reuters.com, https://www.reuters. com/article/us-bosnia-imf/imf-discusses-unlocking-loans-to-bosnia-idUSKBN1EC183, 30.06.2018.

IMF Executive Board Approves Three-Year E553.3 Million Extended Arrangement under EFF for Bosnia and Herzegovina (2016), 07.09.2016, Imf.org, http://www.imf.org/en/news/ 
articles/2016/09/07/pr16396-bosnia-and-herzegovina-imf-executive-board-approves-threeyear-extended-arrangement, 30.06.2018.

Instrument for Pre-accession Assistance, European Neighbourhood Policy and Enlargement Negotiations, Ec.europa.eu, https://ec.europa.eu/neighbourhood-enlargement/instruments/overview_en, 30.06.2018.

Joniewicz T., Żornaczuk T. (2012), Przełamanie impasu politycznego w Bośni i Hercegowinie, "Biuletyn PISM," no. 12 (877).

Jukic E. (2014), Bosnia Authorities Under Fire over Flood Response, 21.05.2014, Balkaninsight. com, http://www.balkaninsight.com/en/article/bosnia-authorities-under-fire-over-flood-response, 30.06.2018.

Juncker J.-C. (2014), A New Start for Europe: My Agenda for Jobs, Growth, Fairness and Democratic Change. Political Guidelines for the next European Commission, Strasbourg.

Krysieniel K. (2010), System wyborczy w Bośni i Hercegowinie - spojrzenie krytyczne, "Przegląd Prawa Konstytucyjnego," no. 1.

Krysieniel K. (2011), Między Dayton a Bruksela. Perspektywy transformacji polityczno-ustrojowej w Bośni i Hercegowinie, in: Bośnia i Hercegowina 15 lat po Dayton. Przeszlość - teraźniejszość - perspektywy, eds. P. Chmielewski, S. L. Szczesio, Łódź.

Krysieniel K. (2014), Specyfika rozwiązań ustrojowych w Bośni i Hercegowinie, "Przegląd Prawa Konstytucyjnego," no. 1 (17).

Medina L., Schneider F. (2018), Shadow Economies Around the World: What Did We Learn Over the Last 20 Years?, "IMF Working Paper," no. WP/18/17.

Molendowski E. (2012), Kraje Bałkanów Zachodnich - główne problemy wspótpracy wzajemnej $i$ integracji z Unia Europejska $w$ warunkach globalnego kryzysu, in: Integracja regionalna wobec wyzwań współczesnej gospodarki światowej, ed. E. Molendowski, Warszawa.

Muś J. (2013), Bośnia i Hercegowina. Etnopolityczne podziały i ich uwarunkowania, Lublin.

Petričušić A. (2005), Regional Cooperation in the Western Balkans - a Key to Integration into the European Union, "Croatian Yearbook of European Law and Policy," vol. 1.

Presidency Conclusions, Amsterdam European Council, 16 and 17 June 1997.

Presidency Conclusions, Brussels European Council, 20-21 March 2003.

Presidency Conclusions, Cologne European Council, 3 and 4 June 1999.

Presidency Conclusions, European Council in Copenhagen, 21-22 June 1993.

Presidency Conclusions, Florence European Council, 21-22 June 1996.

Presidency Conclusions, Madrid European Council, 15-16 December 1995.

Presidency Conclusions, Thessaloniki European Council, 19-20 June 2003.

Presidency Conclusions, Vienna European Council, 11-12 December 1998.

Public Opinion Poll Results. Analitical Report (2013), Prism Research for Office of the UN Resident Coordinator in Bosnia and Herzegovina, Sarajevo.

Salzburg EU/Western Balkans Joint Press Statement (2006), Brussels, 11 March 2006, C/06/77, 7283/06, Presse 77.

Sarajlic-Maglic D. (2011), BiH after the elections - a tale of disillusioned optimism, in: The Western Balkans and the EU: 'the Hour of Europe', ed. J. Rupnik, Paris.

Schenker H. (2008), The Stabilization and Association Process: An Engine of European Integration in Need of Tuning, "Journal on Ethnopolitics and Minority Issues in Europe," no. 7.

Stanisławski W. (2008), Sytuacja wewnętrzna państw Bałkanów Zachodnich w kontekście integracji europejskiej. Bośnia i Hercegowina, in: Bałkany Zachodnie a integracja europejska. Perspektywy i implikacje, eds. J. Muś, R. Sadowski, Warszawa.

Stanisławski W., Szpala M. (2009), Bośniacki chaos. Źródła kryzysu politycznego we wspótczesnej Bośni i Hercegowinie, "Prace Ośrodka Studiów Wschodnich," no. 31. 
Stojarova V. (2007), Organized Crime in the Western Balkans, "HUMSEC Journal," issue 1.

Szpala M. (2011), Pozorny sukces UE w Bośni i Hercegowinie, 18.05.2011, Osw.waw.pl, https:// www.osw.waw.pl/pl/publikacje/analizy/2011-05-18/pozorny-sukces-ue-w-bosni-i-hercegowinie, 30.06.2018.

Szpala M. (2012), Bośnia i Hercegowina: stan finansów wymusit kompromis w sprawie rządu, 04.01.2012, Osw.waw.pl, https://www.osw.waw.pl/pl/publikacje/analizy/2012-01-04/bosniai-hercegowina-stan-finansow-wymusil-kompromis-w-sprawie-rzadu, 30.06.2018.

The Global Competitiveness Report 2017-2018, World Economic Forum, Geneva 2017.

The Global Innovation Index 2017. Innovation Feeding the World (2017), Cornell - S.C. Johnson College of Business, INSEAD - The Business School for the World, WIPI - World Intellectual Property Organization, Geneva.

Treaty on European Union and the Treaty on the Functioning of the European Union. Consolidated versions, Official Journal C 326, 26.10.2012, P. 0001-0390.

Western Balkans to 2025. A brighter future or permanent marginalisation? (2018), A report by The Economist Intelligence Unit, London-New York-Hong Kong.

Żornaczuk T. (2013), Czy Chorwacja ułatwi rozszerzenie UE na Bałkanach Zachodnich?, "Biuletyn PISM," no. 134 (1110).

Żornaczuk T. (2018), EU Enlargement in the Balkans: New Prospects for Resolving Old Challenges, "Biuletyn PISM," no. 39 (1110).

Żurek P. (2011), Bośnia i Hercegowina w wizji politycznej Franjo Tudmana, in: Bośnia i Hercegowina 15 lat po Dayton. Przeszłość - teraźniejszość - perspektywy, eds. P. Chmielewski, S. L. Szczesio, Łódź.

\section{Summary}

In 2018 the European Union (EU) recalled that the future of the Western Balkans lies in the EU. The vision of an "European (Union) future" was announced to the Balkan countries fifteen years earlier, in 2003, when they were recognized as a potential candidates for membership in the EU.

In 2016 Sarajevo decided to apply for membership in the European Union. Therefore, the main aim of this article is to analyse the possibility of joining the EU by Bosnia and Herzegovina. It is necessary to identify - even if chosen - opportunities and challenges, perspectives and barriers on the path to further integration of that country with Brussels. The background of these considerations must be the EU's policy towards the Western Balkans region, which lost its dynamics with the beginning of the second decade of the $21^{\text {st }}$ century, and is trying to retrieve if for various reasons nowadays. Will Bosnia and Herzegovina benefit from the intensification of the EU's enlargement policy?

Key words: The European Union; the EU enlargement policy; Bosnia and Herzegovina, Western Balkans

\section{Integracja Bośni i Hercegowiny z Unią Europejską: szanse, wyzwania i perspektywy}

\section{Streszczenie}

W 2018 roku Unia Europejska (UE) przypomniała, że przyszłość Bałkanów Zachodnich znajduje się w UE. Perspektywa ,europejskiej (unijnej) przyszłości” została zaprezentowana 
państwom bałkańskim już piętnaście lat wcześniej, w 2003 roku, kiedy to zostały one uznane za państwa potencjalnie kandydujące do członkostwa w UE.

W 2016 roku Sarajewo zawnioskowało o akcesję do Unii Europejskiej. Głównym celem niniejszego artykułu jest zatem analiza możliwości przystąpienia Bośni i Hercegowiny do UE. Niezbędne jest zidentyfikowanie - chociażby wybranych - szans i wyzwań, perspektyw i barier na drodze do dalszej integracji tego państwa z Brukselą. Tłem dla rozważań musi stać się polityka Unii Europejskiej wobec regionu Bałkanów Zachodnich, która straciła na dynamice wraz z początkiem drugiej dekady XXI wieku, by w jej końcu próbować ją (z różnych względów) odzyskać. Czy na intensyfikacji polityki rozszerzenia UE może skorzystać Bośnia i Hercegowina?

Słowa kluczowe: Unia Europejska; polityka rozszerzenia UE; Bośnia i Hercegowina; Bałkany Zachodnie 